Walisongo Law Review (Walrev), Vol 2 No. 1 (2020)

DOI: 10.21580/Walrev/2020.2.1.5338

Copyright (C) 2020 Walisongo Law Review (Walrev)

Walisongo Law Review

\title{
Implementation of the Methadone Maintenance Therapy Program for Highrisk Drug Prisoners
}

\author{
Moch Subhan Zakaria
}

Afiliasi: Politeknik Ilmu Pemasyarakatan Cinere, Depok

Email: zakariasubhan@gmail.com

\begin{abstract}
The harm reduction program is a program that aims to assist inmates who use syringes (IDU's) in overcoming dependence on narcotics medically and to prevent the adverse effects caused by narcotics abuse. Where in general the use of heroin is done by injecting using a syringe alternately, or known as "For Wet" This can cause a new problem that is greater that the outbreak of the HIV/AIDS virus. Most prisoners use injecting narcotics before entering prison and have been infected with the HIV virus, so the risk of transmitting HIV/AIDS to other prisoners is very high. The tendency of the number of relapses (reuse) by prisoners who are in the period of coaching is quite high despite the efforts of strict supervision in the security sector, but in fact in several prisons/detention there is narcotics smuggling in various modes. For this reason, the Indonesian Ministry of Law and Human Rights through the Directorate General of Corrections organizes the $\mathrm{P} 4 \mathrm{GN}$ program (Prevention of Eradication of Narcotics Abuse and Circulation) in prisons and detention environments by promoting the principle of "Total Abstinence" meaning that no use of any type of
\end{abstract}


narcotics during coaching in prisons and prisons. But for the type of metadone, which is a type II narcotics can be tolerated because it is used for the purpose of treatment/healing of narcotics dependence and is also a government program implemented by the Ministry of Health as the leading sector.

Program harm reduction adalah program yang bertujuan untuk membantu narapidana pengguna jarum suntik (IDU's) dalam mengatasi ketergantungan terhadap narkotika secara medis dan untuk mencegah dampak buruk yang ditimbulkan akibat penyalahgunaan narkotika. Dimana Pada umumnya pemakain heroin dilakukan dengan cara disuntikan dengan menggunakan jarum suntik secara bergantian, atau dikenal dengan istilah "Bagi Basah" Hal ini dapat menimbulkan masalah baru yang lebih besar yaitu terjangkitnya virus HIV/AIDS. Kebanyakan narapidana menggunakan narkotika suntik sebelum masuk ke dalam Lapas dan sudah terinfeksi virus $H I V$, akibatnya resiko penularan penyakit HIV/AIDS terhadap narapidana yang lain sangat tinggi. Kecenderungan terjadinya angka Relaps (pemakaian kembali) oleh narapidana yang sedang dalam masa pembinaan cukup tinggi walaupun sudah dilakukan berbagai upaya pengawasan yang ketat didalam bidang keamanan, namun faktanya di beberapa Lapas/Rutan terjadi penyelundupan narkotika dengan berbagai modus. Untuk itu Kementerian Hukum dan Ham RI melalui Direktorat Jenderal Pemasyarakatan menyelenggarakan program P4GN (Pencegahan Pemberantasan Penyalahgunaan dan Peredaran Gelap Narkotika) dilingkungan Lapas dan Rutan dengan mengedepankan prinsip "Total Abstinensia" artinya bahwa tidak boleh ada penggunaan jenis narkotika apapun selama proses pembinaan didalam Lapas. Namun untuk jenis metadone, yang merupakan jenis narkotika golongan II dapat ditoleransi karena digunakan untuk tujuan pengobatan/penyembuhan terhadap ketergantungan narkotika dan juga merupakan program pemerintah yang dilaksanakan oleh Kementerian Kesehatan sebagai leading sektornya.

Keywords: Drug Addiction; HIV/AIDS; Metadone; Inmate. 


\section{Introduction}

In view of the current development of Narcotics, Psychotropic and Other Addictive Substances (NAPZA) or popular terms known by the public as Narcotics (Narcotics, Psychotropic and Other Addictive Materials) is a very complex problem and requires comprehensive coping efforts involving multidisciplinary cooperation, multisector, and active community participation that is carried out continuously, comprehensively, consistently and consistently. In the medical world, most Narcotics, Psychotropic and other addictive substances (NAPZA) are used for treatment, but if abused or used not according to medical indications or treatment standards, it will result in very dangerous for individuals and the wider community, especially the younger generation.

The Ministry of Law and Human Rights of the Republic of Indonesia through the Directorate General of Corrections organizes the P4GN program (Prevention of Eradication of Narcotics Dark Abuse and Circulation) in prisons and detention environments by prioritizing the principle of "Total Abstinence" meaning that no use of any type of narcotics during coaching in prisons and prisons. But for the type of metadone, which is a type II narcotics can be tolerated because it is used for the purpose of treatment or healing of narcotics dependence and is also a government program implemented by the Ministry of Health as the leading sector.

Based on the Law of the Republic of Indonesia No. 35 of 2009 concerning Narcotics which is a revision of Law No. 22 of 1997 concerning Narcotics, it is stated that what is meant by Narcotics is: "Substances or drugs derived from plants or non-plants, both synthesis and semi-synthesis that cause a decrease or change in consciousness, loss of taste, reduce to eliminate pain and can cause dependence," (article 1). (Zat atau obat yang berasal dari tanaman/bukan tanaman, baik sintesis maupun semi sintesis yang menyebabkan penurunan atau perubahan kesadaran, hilangnya rasa, mengurangi sampai menghilangkan rasa nyeri dan dapat menimbulkan ketergantungan," (pasal 1)). 
An increase in narcotics abuse cases also results in an increase in the number of prisoners of narcotics cases in Penitentiary. In Law No. 12 of 1995 concerning Penitentiary, stated "Penitentiary hereinafter referred to as Lapas is a place to carry out the formation of prisoners and correctional students". This includes drug prisoners who have been increasing in numbers lately.

The Correctional System known in Indonesia since April 27, 1964 is a guideline for fostering prisoners. Penitentiary system according to Law No. 12 of 1995 concerning Corrections, article 2 is: "An order regarding the direction and boundaries and ways of fostering Corrections based on Pancasila that is carried out and integrated between the coaches, who are fostered and the community, aims to form a Correctional Community in order to become fully human, realize mistakes, improve themselves, and do not repeat criminal acts so that they can be accepted returned by the community environment, can actively play a role in development, and can live properly as a good and responsible citizen." (Suatu tatanan mengenai arah dan batas serta cara pembinaan Pemasyarakatan berdasarkan Pancasila yang dilaksanakan serta terpadu antara Pembina, yang dibina dan masyarakat, bertujuan untuk membentuk warga binaan Pemasyarakatan agar menjadi manusia seutuhnya, menyadari kesalahan, memperbaiki diri, dan tidak mengulangi tindak pidana sehingga dapat diterima kembali oleh lingkungan masyarakat, dapat aktif berperan dalam pembangunan, dan dapat hidup secara wajar sebagai warga yang baik dan bertanggung jawab.)

Misuse of narcotics, especially in cases of drug addiction, heroin which is a type I narcotics, is the most abused in the community. Data in general in Indonesia in 1995 estimated that 130.00 people (0.065\%) had used heroin. The heroin users are mostly young people under the age of 26 years. The death rate due to the use of heroin in Indonesia reached $17.6 \%$. In general, the way to use heroin is done by injection or inhale (inhale) through the mouth or nose, its use by heating it on aluminum foil paper and then inhaling using Bong. The main properties are analgesic (relieve 
pain), euphoria (feeling happy and prosperous) and cause drowsiness. Repeated use can lead to penances and dependencies.

In general, the use of heroin is done by injection using a syringe alternately, or known by the term "For Wet" This can cause a new problem that is greater that the outbreak of HIV/AIDS. Most prisoners use injecting narcotics before entering prison and have been infected with the HIV virus, so the risk of transmitting HIV/AIDS to other prisoners is very high. The tendency of the number of relapses (reuse) by prisoners who are in the period of coaching is quite high despite the efforts of strict supervision in the security sector, but in fact in several prisons/detention there is narcotics smuggling in various modes.

By looking at the problems caused by the HIV/AIDS virus that occur in the Penitentiary/State Detention Center, the Directorate General of Corrections, through the Directorate of Health Care and Care of Prisoners and Detainees decided to implement a program of Harm Reduction through the Methadone Maintenance Therapy Program (Methadone Maintenance Therapy Program) PTRM) in 9 (nine) prisons/detention centers in Indonesia as a pilot program including Lapas IIA Narcotics Lapas Jakarta, Lapas Klas I Jakarta, Lapas Klas II Pondok Pondok, Klutan IIA Salemba Jakarta, Lapas Klas IIA Pemuda Tanggerang, Klas Klas I Jakarta IIA Banceuy, Class IIA Detention Center Bandung, Lapas Class IIA Denpasar, and Class I Detention Center Medan.

Methadone is a synthetic opiate that has a longer working power and is more effective than morphine and heroin with ingested/oral use. Methadone can be misused by injection to replace morphine and heroin type narcotics.

Based on the above considerations, the author is interested in discussing further about the methadone maintenance therapy program implemented in prison, bearing in mind that it is very difficult to overcome the adverse effects of narcotics, as well as the importance of the implementation of methadone maintenance therapy program in Penitentiary Institutions as a means of supporting counseling programs for prisoners. For this reason, the 
authors will conduct research on the methadone maintenance therapy program related to the extent to which methadone therapy can overcome the adverse effects of narcotics for prisoners of narcotics abuse.

\section{Focus of Study}

Guidance and guidance carried out by supervisors in the Penitentiary System must go through stages, namely: administration/orientation, coaching and assimilation and integration in society (Jaya 2005:38):

a. The admission and orientation phase, starting from the socialization of the community, enters the institution with an activity, including an introduction to the atmosphere of the institution, agency/supervisors, discipline/discipline, rights and obligations while being institutionalized. The period of admission stage is 1 (one) week for detainees and 1 (one) month for prisoners. At this stage it is known as environmental recognition and research (Mapenaling).

b. The coaching phase, carried out on $1 / 3$ (one-third) to $1 / 2$ (onehalf) of the criminal period, at this stage the supervision is done very tight (maximum security) with the aim that prisoners can adjust to the environment and regulations -the rules that apply especially in terms of behavior.

c. Assimilation phase, the implementation starts $1 / 2$ (one half) to $2 / 3$ (two thirds) of the criminal period. At this stage the prisoners' fostered citizenship with identity (intelligence, mentality, and faith) was introduced in more depth to the community around the institution through sports, scouts and others. At this stage supervision is somewhat reduced (medium security). d. The integration phase is carried out after the prisoners undergo 2/3 (two thirds) of the criminal period until the end of the criminal period. At this stage supervision has been greatly reduced (minimum security). For correctional prisoners who are truly aware and well behaved based on observations of the correctional observer team can propose: regular leave, leave before release, and parole. 
Guidelines for handling High Risk Prisoners are regulated in Regulation of the Director General of Corrections Number PAS58.OT.03.01 of 2010 concerning the Permanent Procedure for the Treatment of High Risk Prisoners (SOPs for the Treatment of High Risk Prisoners). Special treatment or different treatment of high risk prisoners due to the needs and risks inherent in him. The moral basis of such treatment is that different treatments do not always mean that they have violated the principle of equality of treatment and service (the principle of non-discrimination). In addition, this different treatment is in accordance with the principle of individualization of guidance as recommended in point 52 Implentation of the Standard Minimum Rules for the Treatment of Prisoners and in accordance with article 12 (1) of Law Number 12 of 1995 concerning Corrections.

Risk assessment is a systematic method for determining whether an activity has an acceptable risk or not. There is a risk assessment, an analysis process, and interpret risks with certain basic activities. Broadly speaking, the elements of risk analysis referred to include:

a. Risk Identification, identifying possible risks (categorization) and mapping the causes, impacts and consequences of those risks. The results of this stage include two things, namely: identification of risks (type, description, causes, impacts, and control of risks) and risk areas (risk areas and sub-areas);

b. Risk Analysis, analyzing the risks that might occur (side effects/losses, mitigation efforts, etc.), conducting an assessment or risk assessment with the aim of knowing the level of risk that exists and the level of risk that must be reduced; so that it will produce the remaining risk, and;

c. Risk Evaluation, conduct periodic reviews of various potential risks.

Risk Assessment is an assessment conducted to determine the level of risk of criminal offenses of prison inmates or correctional clients. Needs Assessment is an assessment conducted to determine the most appropriate guidance or coaching needs for 
prisoners or correctional clients based on factors that contribute to the criminal offenses committed. Risk and needs assessment must be repeated periodically and can be done every year by reviewing the results of previous assessments and if there is new information that can affect changes in the level of risk of criminal repetition can be done again. Adjustment of the level of security and the appropriate level of risk depends on the findings of the assessment.

High-risk prisoners must be dealt with by implementing a range of actions aimed at reducing the risk of committing acts of violence when inside, or recidivating after being released. The risk management strategy must be included in both rehabilitative and restrictive measures and periodically evaluated. The purpose of this formation is that high-risk prisoners become good again when in the community. Management of high-risk prisoners, especially coaching plans, cannot be successful without beginning with a risk assessment. Assessments must be carried out by prisons to determine whether prisoners pose a risk to themselves and others. Assessments must be made when a first inmate goes to prison and is repeated periodically. This assessment begins during the trial period to provide information on the most appropriate categorization and placement of detainees before the sentence.

\section{Research Method}

The high level of narcotics abuse is nothing new in the lives of the world community. In Indonesia too, from year to year there has been an increase in narcotics abuse, all of which can be seen in the data available at the National Narcotics Agency (BNN) in 2009/2010. This figure shows that, the problem of narcotics abuse in Indonesia has penetrated the majority of the community, as noted also that, currently according to research conducted by the National Narcotics Agency (BNN), the result is 1.5\% of Indonesia's population, namely around 2.9 million to 3.2 million people are involved in narcotics abuse.

Narcotics abuse has a negative and very detrimental effect, also very bad effect on mental and physical health. Therefore abused drugs and narcotics can have various effects. This problem not only 
has a negative impact on victims/abusers, but more broadly has a negative impact on family and community life, the economy, public health, security, order, and even the loss of generations as the successor of the nation (lost of generation).

The increase in narcotics abuse cases in the community has also resulted in an increase in the number of prisoners in Penitentiary. This prompted the Directorate General of Corrections, through the Directorate of Prisoners' Care and Health of Prisoners and Detainees to carry out the Methadone Maintenance Therapy (PTRM) program to tackle the adverse effects of narcotics for special prisoners of narcotics abuse in the State Penitentiary/State Detention Center.

In this writing, the writer will use a descriptive analysis research method, which is describing the implementation of a methadone maintenance therapy program for narcotics prison inmates with the aspects contained therein, then analyzed and concluded using a qualitative approach.

\section{Research Result}

The implementation of the Methadone Maintenance Therapy Program has been going well but there are several obstacles that have been found so that the implementation of the Methadone Maintenance Therapy Program is hampered. These problems include the following:

\section{Facilities and infrastructure}

There is still a lack of facilities and infrastructure that support the implementation of health service programs in Jakarta Narcotics Prison, especially the availability of special rooms such as rooms for STI clinic services, VCT (Voluntary Counseling and Testing), ART (Anti Retroviral), and PTRM (PTRM) Methadone Maintenance Therapy Program). Some problems that become obstacles in the implementation of various service activities programs include:

a. The unavailability of adequate service room settings for each PTRM service activity, including a special place for storage of liquid methadone that meets narcotics storage 
standards and a special place for storing empty bottles of used methadone on satellites.

b. The unavailability of online communication tools (internet systems) at PTRM, both from providers and satellites.

c. There is no mechanism yet for the distribution of liquid methadone from Pengampu Hospital to satellite.

d. The system of recording and reporting is not yet well organized and orderly, causing monthly reports on the use of methadone to hospitals and BPOM to be inaccurate.

e. Regarding the calibration of the equipment used, since 2004 there has never been a calibration of measuring devices for methadone administration. For example, the methadone dispensing device used to remove methadone from a bottle does not meet the requirements that should be, when officers want to remove $10 \mathrm{~mm}$ of methadone from the bottle, after pumping the amount that comes out as much as $12 \mathrm{~mm}$ or vice versa. This condition makes it difficult to report the use of methadone to BPOM and Hospital.

\section{Budget / Funding}

Budget/funds is a very important supporting tool for the running of a program/activity. In carrying out its activities the budget available through DIPA is very limited, the health budget is not only for Methadone Maintenance therapy activities but also for treatment of other diseases such as STI, TB, Hepatitis, Herpes, etc. For this reason, support from third parties from the government through KPAN and NGOs is very important to support the implementation of the Metadone Maintenance Therapy Program. In the implementation of the methadone program there are several funding issues that need attention including the lack of funds available to carry out support activities (for consumption, transportation and other facilities) and inadequate incentives for medical personnel who perform tasks outside official hours and lack of funds to conduct laboratory examinations when screening in a maintenance program and urine test. 


\section{Human Resources (HR) Problems}

a. Training on the Methadone, Drug and HIV / AIDS Maintenance Therapy Program

The officer factor plays a very important role in realizing the success of fostering inmates at the Penitentiary, for that officers should have competent knowledge, so that they can carry out their duties and obligations in professionally guiding prisoners.

Of the officers who have received training, do not transfer knowledge to other officers or assistants so that the number of officers who have knowledge and skills in the PTRM field is very limited.

b. Security system problems that result in illicit drug trafficking in Penitentiary

Illicit drug trafficking not only circulates among the outside community but also occurs in the Penitentiary and the State Detention Center. Because the Penitentiary and the State Detention Center are miniatures of community life, what happens in the community also occurs at the Penitentiary and the State Detention Center. This was proven by the arrest of prisoners who were found to be storing heroin type narcotics in a residential block room during routine searches every month.

The rise of illicit drug trafficking in Penitentiary has resulted in constraints on therapies implemented to reduce narcotics use, and it is not even possible that the efforts made are in vain. This is because the abuser always tries to obtain and consume narcotics in various ways, this happens because of the nature or effect of narcotics which always invites him to return to use (relaps).

\section{Conclusion}

1. The Methadone Maintenance Therapy Program that has been implemented at the correctional facility is a harm reduction program whose core purpose is to assist inmates using IDUs in 
overcoming dependence on narcotics medically and to prevent adverse effects caused by narcotics abuse. This program is a newly developed program in several prisons, financial support in the implementation of this program is very limited but activities can still run with the support of the Ministry of Health, Medical Hospital (Drug Dependency Hospital) and third parties.

2. The success of the guidance program for narcotics prisoners through the PTRM program is highly dependent on the success of the P4GN program (the Program for the Prevention, Eradication of Narcotics Abuse and Circulation) which is carried out in prisons. Sterile prison conditions from narcotics illicit trafficking are needed to support the success of the entire training program.

3. The Methadone Maintenance Therapy Program uses methadone facilities in a liquid preparation, where the treatment is taken by mouth (oral).

4. Methadone is a class II narcotics which is efficacious for treatment, is used as a last resort and can be used in therapy and / or for the purpose of scientific development and has high potential to cause dependence. $[\mathrm{w}]$

\section{Reference}

Badan Narkotika Nasional Republik Indonesia (BNN RI). 2008. Survey Ekonomi Akibat Penyalahgunaan dan Peredaran Gelap Narkoba di Indonesia. Jakarta: Puslitbang dan Info Lakhar BNN RI.

Departemen Kesehatan RI, Komisis Penanggulangan AIDS, USAID. 2007. Surveilans Terpadu-Biologis Perilaku pada Kelompok Beresiko Tinggi; Rangkuman Surveilans Pengguna Jarum Suntik. Jakarta: Depkes RI.

Direktorat Jenderal Pengendalian Penyakit dan Penyehatan Lingkungan Kementerian Kesehatan Republik Indonesia (Ditjen PP \& PL Kemenkes RI). 2014. Laporan 
perkembangan HIV-AIDS Triwulan III Tahun 2014. Jakarta: Kemenkes RI.

Guntur, A. 2011. Evaluasi Pelaksanaan Program Terapi Rumatan Metadon Pada Pecandu Heroin di Gunung Kidul Yogyakarta. Jurnal Kesehatan Masyarakat, 37 (32): 157170.

Isfandari, S., Hanati, I,N., Asliati, A., Utami, D,S., Martdiati, R., Sarasvita, R. 2009. Terapi Rumatan Metadone: Ketanggayan Pasien, Sikap Staff dan Penerimaan Masyarakat. Bul. Penel. Kesehatan, 37 (1): 33-42.

Jaya, Serikat Putra. 2005. Kapita Selekta Hukum Pidana. 2nd ed. Semarang: Universitas Dipenogoro Press.

Nahrisah, P. 2008. Evaluasi Program Terapi Rumatan Metadona Pada Pecandu Heroin di Puskesmas Kecamatan Tabet. Jurnal Kesehatan Masyarakat: UI, 2 (4): 40-53. 